\title{
Plasma and bronchoalveolar lavage samples in acute lung allograft rejection: the potential role of cytokines as diagnostic markers
}

\author{
Nicole E. Speck ${ }^{1}$, Macé M. Schuurmans ${ }^{1}$, Christian Benden ${ }^{1}$, Cécile A. Robinson ${ }^{1}$ and Lars C. Huber ${ }^{2^{*}}$
}

\begin{abstract}
The role of differential cytology patterns in peripheral blood and bronchoalveolar lavage samples is increasingly investigated as a potential adjunct to diagnose acute and chronic allograft dysfunction after lung transplantation. While these profiles might facilitate the diagnosis of acute cellular rejection, low sensitivity and specificity of these patterns limit direct translation in a clinical setting. In this context, the identification of other biomarkers is needed. This review article gives an overview of cytokine profiles of plasma and bronchoalveolar lavage samples during acute cellular rejection. The value of these cytokines in supporting the diagnosis of acute cellular rejection is discussed. Current findings on the topic are highlighted and experimental settings for future research projects are identified.
\end{abstract}

Keywords: Blood, Bronchoalveolar lavage, Cytokine, Diagnosis, Graft rejection, Lung transplantation, Plasma

\section{Background}

Lung transplantation is an established therapeutic option for selected patients with end-stage lung disease. While survival after lung transplantation has increased over time due to improved survival in the early post-transplant period, chronic lung allograft dysfunction (CLAD) and infections are the main factors limiting long-term survival [1] Acute cellular rejection (ACR) is a potential risk factor for the development of CLAD [2-4]. The gold standard to detect ACR is histopathological grading of transbronchial biopsies (TBB). However, these biopsies are invasive and accurate grading is limited by sampling error and interobserver variability [5-7]. Furthermore, the clinical relevance of low grade (A1) rejection is controversial and treatments vary between centres [8-10].

We have recently reviewed the role of differential cytology patterns in samples obtained from peripheral blood $(\mathrm{PB})$ and bronchoalveolar lavage (BAL) for the development of ACR [11]. While these profiles show interesting trends that may facilitate early diagnosis and

\footnotetext{
* Correspondence: lars.huber@triemli.zuerich.ch

${ }^{2}$ Clinic for Internal Medicine, City Hospital Triemli, Birmensdorferstrasse 497,

$\mathrm{CH}-8063$ Zurich, Switzerland

Full list of author information is available at the end of the article
}

treatment of ACR, low sensitivity and specificity of these findings limit the clinical utility and, currently, preclude the isolated use of cellular patterns for the diagnosis of ACR. In this context, identification of other biomarkers is needed to improve the diagnostic performance of cytokine patterns for diagnosis of AR. We summarise here the experimental and clinical evidence on cytokine profiles in BAL and plasma samples during ACR, discuss limitations and outline areas for future research.

\section{Methods}

We searched the electronic databases Medline (Bethesda, MD, USA: U.S. National Library of Medicine), EMBASE (Amsterdam, NL: Elsevier B.V.) and Web of Science Core Collection (New York, NY, USA: Thomson Reuters). Medical subject heading (MeSH) terms included "cytokines", "bronchoalveolar lavage", "blood plasma", "graft rejection" and "lung transplantation".

Publications were eligible if they provided information on cytokine patterns in BAL or PB during ACR. We considered articles published in English until 31 October 2016. This included experimental studies, prospective and retrospective clinical studies, review articles and case reports. No other restrictions were applied. We 
Table 1 Types and number of references included in this review article

\begin{tabular}{lllll}
\hline Content & Study design & $\begin{array}{l}\text { Number of } \\
\text { studies included }\end{array}$ & $\begin{array}{l}\text { Number of } \\
\text { patients }\end{array}$ & $\begin{array}{l}\text { Number of } \\
\text { samples }\end{array}$ \\
\hline Cytokines & Experimental & 9 & - & - \\
& Prospective & 13 & 407 & $\begin{array}{l}1301 \mathrm{BAL} \\
17 \text { serum }\end{array}$ \\
& & & & $834 \mathrm{BAL}$ \\
& Retrospective & 12 & 492 & 58 serum \\
& & & & - \\
Total & Review article & 4 & - & $2135 \mathrm{BAL}$ \\
& & 38 & 899 & 75 serum \\
\hline
\end{tabular}

then selected those articles that fulfilled our inclusion criteria. Additionally, we scanned the references of all selected articles to find additional literature that was related to our research question. Finally, 38 papers were eligible to be included in our review. A list of the type and number of articles included is provided in Table 1.

We then evaluated the selected articles and compiled an extensive table, listing every cytokine, the reference that mentioned this parameter as well as the observed data. While writing the review article more papers were drawn on for background information. Each author reviewed the entire document and provided input before the final manuscript was completed.

\section{Cytokines in BAL and plasma samples}

Cytokines influence inflammatory and immune reactions by mediating communication between cells. Cytokines are cell-derived non-antibody proteins, peptides or glycoproteins that activate cells in an autocrine or paracrine fashion and result in stimulatory or inhibitory effects [12]. They play a vital role in recruitment, activation, proliferation or differentiation of regulatory and effector cells of the immune system [13]. Cytokines can be divided into six groups according to their functional or structural similarities (overview provided in Table 2). While cytokines function in a complex network with a degree of redundancy, the effects of certain cytokines on specific cell types are still under investigation [12].

Cytokines influence success and outcome of organ transplantation substantially $[14,15]$. Allograft rejection is a multifactorial process, resulting from integration of different components of the immune system [15]. Initial activation of the innate immune system due to local tissue damage and ischemia-reperfusion injury might trigger and amplify the subsequent dysregulation of the adaptive immune response. Cytokines are produced during both phases of this process [15]. ACR has been associated with dysregulated expression of cytokines in different solid organ transplants [16-18].

Multiple ways to measure and quantify the expression of cytokines in BAL fluid and plasma samples exist, including immunohistochemistry [19], in situ hybridization [19], real-time polymerase chain reaction (RT-PCR) [20], enzyme-linked immunosorbent assays (ELISA) [21], flow cytometry (FCM) [22], bioassays [23], and other immunoassays [12]. ELISA allows detection of proteins; the concentration of the respective molecule can then be interpolated from standard curves. As such, it is the most frequently used technique [12]. Multi-parameter FCM allows quantifying many immune cell subsets and cytokine mediators with great flexibility [24]. Among novel molecular methods, microarrays permit the screening of a large number of genes, while polymerase chain reaction (PCR) is more useful to address hypotheses [25].

Many factors can potentially influence the measurements of cytokine levels, and the awareness of these factors is low [12]. Analysing cytokines in BAL fluid during rejection is further challenging since the alveolarcapillary barrier loses integrity and, subsequently, is more permeable to serum proteins during rejection [14].

Although promising results have been achieved in several areas of medical investigation, cytokines are not routinely measured in clinical practice $[12,26]$. The comparability between the above-mentioned methods is unclear as the influence of various analytical and

Table 2 Overview of six groups of cytokines

\begin{tabular}{|c|c|c|}
\hline Group & Characteristic feature & Reference \\
\hline Interleukin (IL) & $\begin{array}{l}\text { Large number of cytokines named with a numeric suffix roughly in the } \\
\text { order of discovery or molecular characterization. }\end{array}$ & [91] \\
\hline Interferon (IFN) & $\begin{array}{l}\text { Named for their function to interfere with viral infection, inhibiting viral } \\
\text { replication within host cells. }\end{array}$ & [92] \\
\hline Tumor necrosis factor (TNF) superfamily & $\begin{array}{l}\text { Structurally homologous transmembrane proteins that typically form } \\
\text { homotrimers. }\end{array}$ & [73] \\
\hline Transforming growth factor (TGF) superfamily & Involved in both tumor development and dissemination. & [93] \\
\hline Colony-stimulating factor (CSF) & $\begin{array}{l}\text { Stimulate proliferation and expansion of bone marrow progenitor cells, } \\
\text { leading to formation of erythrocytes, granulocytes, monocytes and } \\
\text { lymphocytes. }\end{array}$ & [94] \\
\hline Chemokine & $\begin{array}{l}\text { Structurally homologous, low-molecular weight cytokines that promote } \\
\text { movement and migration of all immune cells between blood and tissue. }\end{array}$ & [95] \\
\hline
\end{tabular}


pre-analytical factors on the results are complex and still need to be elucidated [12].

Table 3 and Table 4 list several cytokines that are present in BAL and PB samples. Moreover, anticipated changes during ACR and both sensitivity and specificity for the diagnosis of ACR are reported when available. Figure 1 shows a proposal for an integrative algorithm with clinical data, radiographic findings, BAL microbiology studies, BAL differential cytology and selected cytokines obtained from BAL and PB samples. Data concerning differential cytology are based on a previous review article in this journal [11]. Specific constellations in the levels of these factors might increase the suspicion for ACR. However, standardization of BAL techniques and detection methods are needed. Appropriate cut-off levels can then be determined for selected parameters to diagnose ACR based on this algorithmic approach. Cytokines and biomarkers involved are discussed below.

\section{IL-1}

Interleukin-1 (IL-1) is a multifunctional pro-inflammatory cytokine, affecting nearly every cell type [27]. Two genes for IL-1 exist: IL- $1 \alpha$ and IL-1 $\beta$. In the context of transplantation, IL-1 $\beta$ has been associated with graft-versushost disease (GVHD), ischemia-reperfusion-injury and the development of bronchiolitis obliterans (BO) [28-30].

Clinical studies observed an increase of IL-1 during periods of ACR. As such, IL- $1 \beta$ was significantly higher in patients with ACR compared to patients without rejection in a prospective study [31]. Moreover, the level of IL- $1 \beta$ was significantly raised during episodes of rejection compared to periods before rejection underlining the potential role of IL-1 as discriminator between rejection and infection. Another study found that BAL alveolar macrophages (AM) of patients with ACR expressed significantly more IL- $1 \alpha$ and IL- $1 \beta$ compared to lung transplant recipients without rejection [32].

IL-1 is elevated during ACR and might be a useful marker to distinguish between allograft rejection and allograft infection.

\section{IL-4}

IL-4 is an anti-inflammatory cytokine released by type 2 helper T cells (Th2 cells), basophils and mast cells [33]. While the effects of IL- 4 in Th2 cells has been extensively studied, the response to IL- 4 in other $\mathrm{T}$ cell types appear to be equally important [33].

Results on IL-4 in clinical studies are inconclusive. IL-4 could not be detected in AM from BAL samples in patients with rejection, infection and absence of both conditions [32]. In another study, the relative amount of
T cells expressing IL-4 did not change between stable and rejecting groups [34].

Whitehead and colleagues identified IL-4 as a potentially useful marker for ACR [16]. When studying cytokines in BAL and PB samples from 31 lung transplant recipients, the authors detected IL-4 messenger RNA (mRNA) in less than $20 \%$ of all samples. Interestingly, IL-4 was not found in samples obtained from patients with infection. The greatest difference was observed when samples of patients with AR were compared to patients without AR. In addition, cytokine gene expression levels varied considerably between $\mathrm{PB}$ and BAL samples. This observation was confirmed in another study, where $\mathrm{T}$ cell cytokine production in BAL and $\mathrm{PB}$ was compared in stable lung transplant recipients and healthy volunteers [35]. In both groups, T cells (CD4+ and CD8+) produced significantly more IL-4 in BAL compared with PB. Furthermore, CD8+ T cells in BAL expressed significantly more IL-4 in transplant recipients than in healthy controls.

Expression of IL-4 during ACR is unclear. IL-4 might not be found in lung transplant recipients with infection.

\section{IL-6}

IL-6 is one of the major pro-inflammatory cytokines that mediates hepatic acute-phase response [36]. In the lungs, IL-6 has been identified as a key player in vascular remodelling and pulmonary hypertension (reviewed in [37]).

The pro-inflammatory role of IL- 6 in ACR has been investigated in both experimental and clinical studies. Rolfe and colleagues observed a bimodal pattern of IL-6 production in BAL fluid in an experimental in vivo model [38]. The investigators transplanted incompatible left lung allografts from Brown Norway rats into Lewis rats. IL-6 mRNA levels were increased in BAL fluid of the transplanted lung on day one and were decreased by day four before increasing again on day six compared to the native lung. The observed pattern coincided with histopathologic changes consistent with ACR.

IL-6 tends to be increased in BAL samples during ACR. As such, IL-6 was elevated during ACR in a recent prospective study [31]. However, this increase was not significant and it is of note that diagnosis of ACR was not based on TBB but on clinical and radiological criteria. IL-6 was also increased in BAL samples during ACR in another clinical study [16]. IL-6 and IL-4 increases were found more often in patients with ACR than any other cytokines changes. Similarly, IL-6 protein was higher in lung transplant recipients with histopathogical proven ACR compared 
Table 3 Observed expression of cytokines in BAL samples during ACR

\begin{tabular}{|c|c|c|c|c|c|}
\hline Cytokine & Expression in BAL & Reference & Measure & $\begin{array}{l}\text { Sensitivity } \\
\text { PPV }\end{array}$ & $\begin{array}{l}\text { Specificity } \\
\text { NPV }\end{array}$ \\
\hline \multirow[t]{5}{*}{ IFN- $\gamma$} & $\uparrow$ & {$[55]$} & mRNA; during early ACR only & & \\
\hline & $\uparrow$ & {$[40,56]$} & mRNA & $\begin{array}{l}77.7 \% \\
73.6 \%\end{array}$ & $\begin{array}{l}85.7 \% \\
88.2 \%\end{array}$ \\
\hline & $\uparrow$ & [71] & Total RNA & & \\
\hline & 0 & [41] & mRNA & & \\
\hline & - & [72] & mRNA & & \\
\hline \multirow[t]{6}{*}{ TNF- a } & $\uparrow$ & {$[38,69,74]$} & mRNA (experimental) & & \\
\hline & $\uparrow 0$ & [31] & Protein & & \\
\hline & 0 & [41] & mRNA & & \\
\hline & $\downarrow$ & [96] & mRNA expressed by AM & & \\
\hline & $\uparrow$ & [43] & mRNA expressed by AM & & \\
\hline & 0 & [97] & mRNA expressed by mononuclear cells & & \\
\hline \multirow[t]{2}{*}{ TGF- $\beta$} & - & [71] & mRNA & & \\
\hline & $\downarrow \ldots \uparrow$ & & $\begin{array}{l}\text { mRNA expressed by AM; dramatic increase } \\
15 \text { days after onset of ACR }\end{array}$ & & \\
\hline \multirow[t]{2}{*}{ IL-1 } & $\uparrow$ & [31] & Protein & & \\
\hline & $\uparrow$ & {$[32]$} & mRNA expressed by AM & & \\
\hline \multirow[t]{2}{*}{ IL-2 } & 0 & {$[55,56]$} & mRNA & $\begin{array}{l}44.4 \% \\
40.0 \%\end{array}$ & $\begin{array}{l}63.6 \% \\
67.7 \%\end{array}$ \\
\hline & - & {$[32]$} & mRNA expressed by AM & & \\
\hline \multirow[t]{4}{*}{ IL-4 } & $\uparrow$ & [16] & mRNA & & \\
\hline & $\uparrow$ & {$[35]$} & mRNA expressed by CD8+ T cells & & \\
\hline & 0 & [34] & mRNA expressed by $T$ cells & & \\
\hline & - & {$[32]$} & mRNA expressed by AM & & \\
\hline IL-5 & 0 & [98] & Protein & & \\
\hline \multirow[t]{8}{*}{ IL-6 } & $\uparrow$ & {$[38,99]$} & mRNA (experimental) & & \\
\hline & $\uparrow$ & [16] & mRNA & & \\
\hline & $\uparrow$ & {$[40]$} & Protein & & \\
\hline & $\uparrow 0$ & [31] & Protein & & \\
\hline & 0 & [41] & mRNA & & \\
\hline & 0 & {$[42]$} & Protein & & \\
\hline & $\uparrow$ & {$[32]$} & mRNA expressed by AM & & \\
\hline & $\uparrow 0$ & {$[43,44]$} & mRNA expressed by AM & & \\
\hline \multirow[t]{3}{*}{ IL-8 } & $\uparrow 0$ & {$[31,50]$} & Protein & & \\
\hline & 0 & [51] & Protein and mRNA & & \\
\hline & 0 & {$[42]$} & Protein & & \\
\hline \multirow[t]{2}{*}{ IL-10 } & $\uparrow$ & [31] & Protein & & \\
\hline & 0 & {$[55,56]$} & mRNA & $\begin{array}{l}88.8 \% \\
41.0 \%\end{array}$ & $\begin{array}{l}32.3 \% \\
84.6 \%\end{array}$ \\
\hline \multirow[t]{3}{*}{ IL-15 } & $\uparrow$ & {$[32,61]$} & mRNA expressed by AM & & \\
\hline & $\uparrow$ & {$[62]$} & Blocked IL-2 receptor & & \\
\hline & 0 & [41] & mRNA & & \\
\hline \multirow[t]{2}{*}{ IL-16 } & $(\downarrow)$ & [100] & Protein & & \\
\hline & $(\uparrow)$ & [41] & mRNA & & \\
\hline
\end{tabular}


Table 3 Observed expression of cytokines in BAL samples during ACR (Continued)

\begin{tabular}{llll}
\hline IL-17 & $\uparrow$ & {$[51,66]$} & Protein \\
& $\uparrow$ & {$[51]$} & mRNA \\
& 0 & {$[41]$} & mRNA \\
IL-18 & 0 & {$[101]$} & Protein \\
CXCL10 & $\uparrow$ & {$[39,41]$} & mRNA \\
& $\uparrow$ & {$[80]$} & Protein \\
\hline
\end{tabular}

0 Unchanged

$\uparrow$ Increased

$\downarrow$ Decreased

$\uparrow 0$ Increased without statistical significance

() Confounded effect

- Not detected

with infection and levels of IL-6 were significantly increased during moderate or severe ACR [39]. In another study, IL-6 mRNA in BAL was highest in patients with corticosteroid-refractory histologic ACR [40].

Conversely, other studies found no significant association between IL-6 and ACR [41, 42].

Various researchers have investigated the expression of IL- 6 by AM. Production of IL- 6 by AM in BAL fluid was significantly increased during ACR compared to stable control patients $[43,44]$. When BAL was repeated 15 days later, values had decreased, reaching similar levels as in stable control patients [43]. Furthermore, cytokine production was higher during symptomatic rejection episodes compared to silent rejection episodes and in ISHLT Grade II rejection compared to Grade I rejection. However, both differences were not significant. Similarly, in another study, AM secreted significantly more IL-6 during ACR than in patients without rejection or infection [32].

Monitoring IL-6 in serum after lung transplantation might be beneficial to detect ACR. However, level of evidence is low. Yoshida and colleagues found that a spiked elevation of IL-6 might predict the presence of ACR [45]. The investigators divided 17 patients into four groups according to the pattern of IL- 6 elevation. 13 out of 19 spikes in the group with sharp raises of serum IL-6 levels were associated with histologically or clinically confirmed ACR. Conversely, continuously high levels of IL-6 were characteristic for infection. In another study, IL-6 was increased in serum during ACR, though this

Table 4 Observed expression of cytokines in plasma samples during ACR

\begin{tabular}{llll}
\hline Cytokine & Expression in serum & Reference & Remark \\
\hline IL-6 & $\uparrow$ & {$[45]$} & Spiked elevation \\
& $\uparrow 0$ & {$[46]$} & \\
\hline
\end{tabular}

$\uparrow$ Increased

$\uparrow 0$ Increased without statistical significance was not significant [46]. Interestingly, no association was found between the levels of IL- 6 in serum and BAL.

Increased IL- 6 has been associated with ACR. Monitoring serum levels of IL-6 after lung transplantation might help to detect ACR. However, current level of evidence is low.

\section{IL-8}

IL-8 is a major chemotactic factor for neutrophils secreted by macrophages and respiratory epithelial cells [47]. In the lung, IL-8 is associated with lymphocytic airway inflammation and neutrophilic reversible allograft dysfunction (NRAD) [48, 49].

Some clinical studies have identified an increase of IL-8 in BAL fluid during ACR, yet this was not significant $[31,50]$. Levels of IL-8 did not correlate with severity of ACR [50].

Other investigators did not notice any significant changes between nine rejecting patients and 17 nonrejecting controls as far as levels of IL-8 in BAL were concerned [51]. In a case-control study no significant difference was detected between IL-8 levels in BAL fluid of patients with ACR and stable controls [42]. While IL8 has been clearly linked with CLAD, its role in ACR has yet to be elucidated.

IL-8 has been associated with the development of $\mathrm{BO}$, but a defined role of IL-8 in ACR has yet to be elucidated.

\section{IL-10}

IL-10 is an anti-inflammatory cytokine secreted by Th 2 cells and regulatory $\mathrm{T}$ cells. It attenuates inflammatory response by inhibition of $\mathrm{T}$ cells, monocytes and macrophages [52]. Several experimental in vivo studies showed that administration of IL-10 before transplantation improved graft acceptance and survival [53, 54]. 


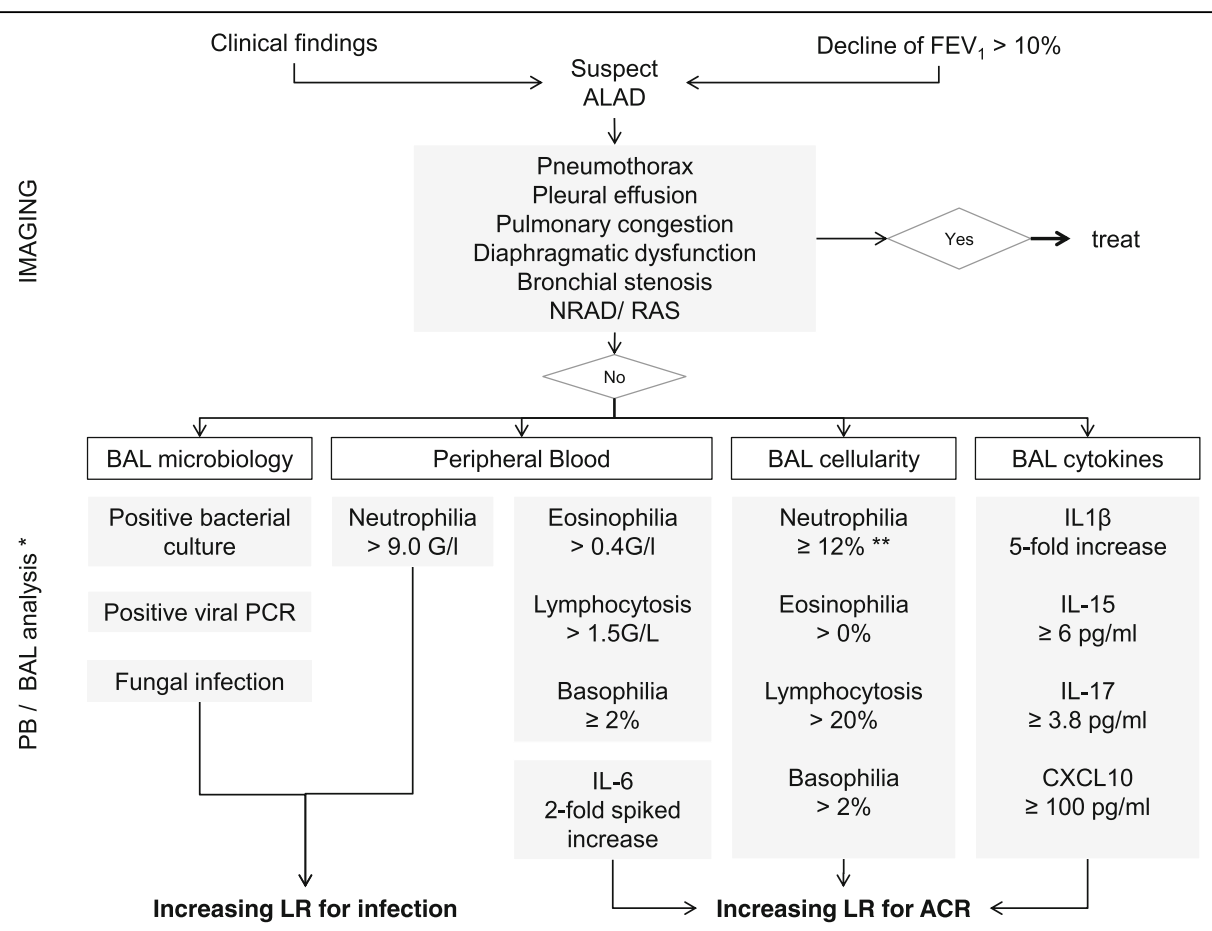

Fig. 1 Proposal of an integrative algorithm. This descriptive algorithm is designed to estimate probabilities for ACR or other causes of ALAD in lung transplant recipients presenting with clinical findings or a drop in lung function ( $\left.\mathrm{FEV}_{1}>10 \%\right)$. The integration of microbiology data, differential cytology [11] and cytokine expression levels from peripheral blood and BAL samples might assist in decision-making to increase or decrease the likelihood for ACR in the context of the clinical presentation. In the absence of standardized BAL techniques and detection methods, BAL cytokine expression levels and cut-offs have to interpreted wth caution and should be confirmed in larger studies. Since results from studies with very different designs have been included, direct translation in a clinical setting is not feasible and the use of this algorithm does not obviate the need for biopsy to confirm or exclude histologyproven ACR. * Numbers vary between different studies. ** Absence of microbiological evidence for infection

Importantly, this effect was not observed when IL-10 was given post transplantation.

Clinical data on IL-10 in BAL are conflicting. IL-10 mRNA was found in most BAL samples of patients who had undergone lung transplantation, irrespective of whether or not ACR was diagnosed [55]. Similarly, levels of IL-10 mRNA did not correlate with ACR in another study, as this cytokine was present in most BAL samples regardless of whether or not ACR was present [56]. In contrast, Patella and colleagues detected an increase of IL-10 levels in BAL fluid during ACR compared to infection and baseline [31]. Interestingly, levels of IL-10 showed opposite trends during infection and ACR. While levels of IL-10 increased during ACR, the expression of IL-10 was low during bacterial and CMV infection.

IL-10 has been attributed a protective role against allograft rejection, as highlighted by lung biopsies from clinical and experimental studies [57, 58]. Zheng and co-workers observed that patients with an increased IL10 production genotype were less likely to have two or more consecutive biopsy specimens of $\geq$ ISHLT Grade A2 rejection despite anti-rejection treatment (steroid bolus, steroid taper or anti-T cell globulin) during the first year post transplantation compared with intermediate or decreased IL-10 production genotypes [57]. The authors suggested that future genetic testing might help to identify patients at risk for multiple episodes of ACR, which might help to tailor therapeutic regimens. The balance between graft destruction and regulation determines graft survival [59]. Regulatory immune cells in a recipient can shift the balance towards graft survival. Interestingly, one of the common features of many regulatory cells is their ability to secrete IL-10 [59]. The observed increase of IL-10 during ACR might thus reflect the attempt to create an anti-rejection microenvironment.

Using a rat model, Oishi and co-workers assessed the effect of ex vivo lipid-mediated transbronchial human IL-10 gene transfer [58] and examined the intra-graft cytokine profile on day three and six after single-lung transplantation between highly histo-incompatible rats. The stage of ACR and different pathologic markers for inflammation were lower in the group receiving intrabronchial plasmids encoding IL-10 compared to the control group receiving mock plasmids. Furthermore, ex vivo lipid-mediated transbronchial human IL-10 gene transfer was associated with lower levels of IL-2 and TNF- $\alpha$ mRNA on day three post transplantation [58]. 
Increased IL-10 has been attributed a protective role against inflammation. BAL levels show no clear consistent pattern. However, IL-10 levels increased in ACR and decreased in infection in one study.

\section{IL-15}

IL-15 is a pro-inflammatory cytokine secreted by multiple tissues and cell types, among which macrophages play a principal role [60]. IL-15 is similar to IL-2 in its structure and biological function. It is a potent chemoattractant factor for $\mathrm{T}$ cells and is involved in B cell maturation and NK cell cytotoxicity [60].

The few results on levels of IL-15 in BAL are promising in the context of ACR. According to Rizzo and colleagues, IL-15 expression by BAL-derived AM was increased in five out of nine patients experiencing ACR compared to patients without rejection and infection [32]. In the other four patients with ACR no IL-15 was detected. In the same study, the authors prospectively assessed cytokines in three patients during and after treatment of ACR, noticing that levels of IL-15 decreased with resolution of ACR. Shi and co-workers found a similar trend: IL-15 mRNA expressed by BAL AM was significantly higher in 15 patients with ACR than in 19 stable controls [61]. In another study, IL-15 protein was elevated in BAL during ACR when the IL-2 receptor was blocked [62]. This study was conducted based on the assumption that IL-2 and IL15 share similar functions and on the observation that blocked IL-2 receptors do not completely avert ACR. Three interesting observations were made: The average IL-15 protein level was increased in acutely rejecting patients compared to stable controls, IL-15 was distributed in a bimodal fashion in patients undergoing ACR, and levels of IL-15 did not correlate with infection. In contrast to the trends mentioned above, Husain and colleagues did not find any significant association between IL-15 and ACR [41].

Elevated IL-15 expressed by AM has been associated with ACR. When the alpha chain subunit of the $\mathrm{IL}-2$ receptor was blocked IL-15 was increased.

\section{IL-17}

IL-17 is a pro-inflammatory cytokine, which is primarily secreted by CD4+ T cells [63]. IL-17 has been reported to play an important role in sustained mobilisation of neutrophils via induction of IL-8 [64]. In this context, it has been linked with chronic inflammatory lung diseases, although its causative role is unclear [65].

Various studies have suggested a role for IL-17 in acute and chronic rejection after lung transplantation $[51,66,67]$. Vanaudenaerde and co-workers found an increase of IL-17 in BAL fluid during ACR on day 28 after lung transplantation [51]. IL-17 mRNA was raised significantly compared to stable controls. IL-17 protein was also increased, however, without reaching significance. At the same time, raised IL-17 protein levels were associated with higher lymphocytes in BAL fluid. Interestingly, IL-17 protein correlated with severity of rejection. When BAL fluid was analysed on day 90 after transplantation, IL-17 was no longer elevated compared with stable control patients. It remains unclear whether this finding is due to immunosuppressive therapy or whether it represents the natural course after ACR. Conversely, Husain and colleagues did not find any association between IL-17 levels and ACR [41].

IL-17 has been associated with mobilisation of neutrophils and chronic inflammatory lung disease. Levels of $\mathrm{IL}-17$ were increased in BAL during ACR.

\section{IFN- $\gamma$}

Interferon gamma (IFN- $\gamma$ ) is a pro-inflammatory cytokine secreted by type 1 helper T cells (Th1 cells) and natural killer cells (NK cells) in response to IL-12 from macrophages. It promotes macrophages to degrade phagocytosed pathogens and inhibits differentiation of Th2 cells [68]. It is further involved in NK cell activity and $B$ cell regulation [68].

IFN $-\gamma$ was found to be raised in animal models during ACR $[69,70]$. In a rat model, Brown Norway rat lungs were depleted of AM before transplantation into Lewis rats [70]. While production of IFN- $\gamma$ was significantly reduced in BAL fluid after transplantation, the development of ACR could not be prevented.

Results obtained in clinical studies remain inconclusive. Expression of IFN- $\gamma$ mRNA in BAL fluid has been associated with ACR in several studies $[55,56]$. In a prospective study mRNA expression of IFN- $\gamma$ in BAL fluid was significantly higher during early ACR (defined by occurrence within three months following transplantation) but not during late ACR [55]. In another study, the presence of IFN- $\gamma$ in BAL fluid predicted ACR with a specificity of $85.7 \%$ and a sensitivity of $77.7 \%$ (positive predictive value (PPV) 73.6\%, negative predictive value (NPV) 88.2\%) [56]. Moreover, when IFN- $\gamma$ gene was expressed during ACR, FEV 1 declined more than in the absence of IFN- $\gamma$ expression. In another study, BAL cell-derived IFN- $\gamma$ mRNA was highest in patients with refractory ACR that did not respond to high-dose intravenous corticosteroid therapy compared to non-rejecting or steroid-responsive control-groups [40]. After treatment with aerosolized cyclosporine IFN- $\gamma$ decreased significantly [40]. By performing gene expression microarrays, IFN- $\gamma$ was found 
to be elevated in all seven samples with ACR whereas it was decreased or absent in the other 27 non-rejection samples [71].

Other studies found no significant association between IFN- $\gamma$ and ACR or failed to detect IFN- $\gamma$ mRNA in BAL samples from patients with ACR [41, 72].

IFN- $\gamma$ has been found at increased levels in BAL samples during ACR.

\section{TNF-a}

Tumor necrosis factor alpha (TNF- $\alpha)$ is a potent proinflammatory cytokine secreted by macrophages, $\mathrm{T}$ cells and NK cells that directs homeostatic and pathogenic functions [73].

TNF- $\alpha$ was increased in animal models during ACR $[38,69,74]$. More specifically, TNF- $\alpha$ was raised at cellular and molecular levels in BAL samples of a rat model [74]. Production of TNF- $\alpha$ mRNA was highest during severe ACR. Moreover, the extent of the bioactivity of TNF- $\alpha$ was shown to correlate with the histopathological grade of rejection. Interestingly, animals receiving intravenous injections with TNF- $\alpha$ antisera before transplantation showed markedly attenuated ACR compared with rats receiving control sera [74]. In another experimental study, donor rat lung allografts (Brown Norway) that had been depleted of AM before transplantation into recipients of a different strand (Lewis) showed significantly lower levels of TNF- $\alpha$ compared with untreated donor lungs in BAL fluid [70]. While this depletion affected the production of several IgG subclasses, it did not prevent the development of ACR.

Data obtained by clinical studies remain unclear. Husain and colleagues found no significant association between the expression TNF- $\alpha$ in BAL fluid and ACR in a prospective study [41]. The authors explained this by the low levels of TNF- $\alpha$ in the BAL samples, probably due to the lower number of AM detected.

In a previous study that analysed levels of TNF- $\alpha$ RNA in 26 BAL and TBB samples, TNF- $\alpha$ was expressed primarily in inflammation due to unspecified causes and less in ACR [72]. Conversely, Patella and colleagues reported an increased expression of TNF- $\alpha$ during ACR, however this finding was not significant [31].

Inconsistent results between studies analysing the expression of TNF- $\alpha$ by AM in BAL might be explained by different methods for culturing macrophages and lack of standardization. However, studies on biomaterials did not show relevant differences in cytokine expression from macrophages by different surface chemistries used to culture these cells [75]. TNF- $\alpha$ was significantly increased in the culture of BAL AM during ACR compared to clinically stable periods [43]. Also, cytokine levels were higher during symptomatic periods of ACR and in ISHLT Grade II rejection compared to asymptomatic periods and grade I rejection, respectively. In BAL samples analysed 15 days after ACR, TNF- $\alpha$ levels had decreased and were comparable to the levels of patients without rejection. In another study AM expressed TNF- $\alpha$ in five out of nine patients during ACR, while TNF- $\alpha$ could not be detected in the remaining four patients [32]. Another study found contrasting results; TNF- $\alpha$ secretion was significantly lower during ACR compared to levels in patients with no complication or infection after transplantation [76].

TNF-a levels were increased in BAL samples of experimental models mimicking ACR. Data in human lung transplant recipients are less clear.

\section{TGF- $\beta$}

Transforming growth factor beta (TGF- $\beta$ ) is an antiinflammatory cytokine also known for its profibrotic role [77]. Dysfunction of TGF- $\beta$ has been observed in autoimmune diseases or in in conditions with impaired immune surveillance [78]. Among the three isoforms TGF- $\beta 1,-\beta 2$ and $-\beta 3$ found in mammals, TGF- $\beta 1$ predominates with strong immune-regulatory properties [79].

Increased TGF- $\beta$ has been linked to the late phase of ACR and tissue repair during an inflammatory reaction. Magnan and colleagues examined the secretion of IL-6 and TGF- $\beta$ by AM during ACR and other complications after lung transplantation [44]. Interestingly, the secretion of IL- 6 and TGF- $\beta$ by AM showed an opposite trend with time: IL- 6 was elevated at the onset of ACR and returned to control values 15 days after diagnosis of $\mathrm{AR}$ and treatment. Conversely, the average concentration of TGF- $\beta$ in AM supernatants was normal at the beginning and increased dramatically by 15 days after onset of ACR. This observation mirrors the inflammatory reaction in lung tissue, characterised by a phase of lung injury, followed by a phase of tissue repair.

In another study that used gene expression microarrays to identify new biomarkers for ACR, TGF- $\beta$ was not found to be up-regulated [71]. However, many downstream mediators were increased, including the TGF- $\beta$ receptor.

TGF- $\beta$ has been associated with the phase of tissue repair and was significantly increased 15 days following ACR and treatment in one study.

\section{CXCL10}

CXCL10 is a chemokine induced by IFN- $\gamma$. It has been shown to promote the directional migration of activated 
$\mathrm{T}$ cells during inflammatory immune responses [80]. CXCL10 has been strongly associated with graft survival after transplantation of various organs, including kidney, heart and GVHD [81].

Increased CXCL10 has been associated with ACR in clinical studies [39, 41]. CXCL-10 was higher in patients with ACR than in patients with infection [41]. This finding might help differentiate ACR from infection in transplant recipients with deterioration of graft function. Agostini and colleagues identified a correlation between high levels of CXCL10 protein in BAL and early ACR (ISHLT Grade A1-A3) and late rejection [80]. The authors furthermore emphasised that CXCL10 and its receptor CXCR3 might provide suitable molecular targets to decrease $\mathrm{T}$ cell recruitment and inhibit $\mathrm{T}$ cellspecific inflammatory processes in the lung. In another study, cumulative exposure of lung allograft recipients to CXCL10 correlated with a significant risk of graft failure [82]. CXCL10 was also elevated before the onset of BO. CXCL-10 might not be specific for rejection processes, as it has also been detected in lungs with sarcoid granulomatous reactions [83].

Elevated levels of CXCL10 have been found in several clinical studies during ACR. The use of CXCL10 as diagnostic marker (or its receptor CXCR3 as therapeutic target) might be limited by the lack of specificity for allograft rejection.

\section{Summary}

Studies about the level of cytokines in BAL during ACR show inconsistent results. This is probably due to discrepancies between BAL techniques, laboratory methods and the complexity of the cytokine network. Nevertheless, changes in cytokine expression have been observed in BAL samples during ACR, among which an increase in IL-1, IL-6, IL-15, IL-17 and CXCL10 seems most consistent.

Few studies assessed cytokine levels in serum. A sharp increase in serum IL-6 seems to be associated with ACR. The scarcity of serum data is likely due to the on-going controversy whether pathological changes in a solid organ of the body are accurately reflected by blood mediators assessed in the systemic circulation [14, 24].

\section{Limitations}

Data from the studies included in this review should be interpreted with caution. Seriously diverging methodologies impair direct comparison between studies and might explain discrepancies in the cytokine profiles between various laboratories investigating the same molecules [11, 12].

At present, measurements of cytokine levels in BAL samples are not standard of care in lung transplant patients. Different BAL techniques and several sampling issues limit the direct comparability of BAL results [84, 85]. More specifically, the composition of BAL fluid is influenced by dilution factors related to the BAL technique, alveolar permeability at the time of sampling and contamination by bronchial fluid $[85,86]$. Moreover, pattern and volume of instilled fluid are important issues and might alter cytokine levels. The ISHLT has recently established a working group on BAL standardization to address these issues in the context of lung transplantation [Tereza Martinu, Toronto, Canada, personal communication].

Furthermore, cytokine detection methods lack standardization and reproducibility [12, 87]. ELISAs are currently the preferred method to measure cytokine levels as outlined above [12]. However, sensitivity of different ELISA kits and reproducibility within the same kit vary substantially, resulting in a wide variation of values $[88,89]$.

Few of the cytokines described in this article have been investigated in a prospective validation study, moreover, data on the levels of healthy controls are rare and no threshold levels have been set for ACR after lung transplantation. Consequently, such cut-off levels should be defined and sensitivity, specificity and predictive values should then be established in a multi-centre cohort study.

All these factors limit comparability, conclusions and direct translation of these findings into a clinical setting. For future research it is imperative that the methods to identify potential biomarkers of ACR are standardised and validated. Potential molecules should then be assessed prospectively in multi-centre studies with large cohorts, using consistent, validated methods.

Standardized retrieval and detection methods would ultimately allow reliable data analysis and integration. Considering the pleiotropic nature and redundancy of cytokines, creating a composite score that integrates several cytokines will enhance the diagnostic value of the BAL cytokine profile. Cytokine patterns could further be merged with changes in cellularity to increase sensitivity and specificity, as seen in the context of CLAD [42]. However, data complexity will make translation into a clinical setting more challenging.

\section{Conclusions}

Changes in cytokines of BAL and plasma samples during $\mathrm{ACR}$ in the lung have been identified. Whereas an increase in IL-1, IL-6, IL-15, IL-17 and CXCL10 in BAL fluid might warrant suspicion for ACR, levels of IL-8 and IL-18 do not appear to be suitable as diagnostic markers during ACR. Data from blood analysis remain weak with very few studies assessing cytokine changes in PB during ACR. A spiked elevation of IL- 6 has been 
associated with ACR. Overall, no strong associations were found that would allow relying exclusively on single cytokine profile changes in BAL or PB samples for diagnosis of ACR. Combinations of cytokine alterations may eventually contribute to a composite score drawing from more than one marker setting (BAL and $\mathrm{PB}$ cytokines and cytology), which may increase diagnostic accuracy and clinical use.

The proposed algorithm in Fig. 1 integrates different clinical data to increase the likelihood for ACR and warrant bronchoscopy to obtain biopsies. It has to be reminded, however, that even TBB and BAL results have limitations for detecting rejection and infection and other causes of allograft dysfunction have always to be considered.

To strengthen the reproducibility of this data it might be beneficial to routinely measure protein levels of IL-1, IL-6, IL-15, IL-17 and CXCL10 when performing BAL analyses during bronchoscopy of asymptomatic patients as well as in patients with suspicion of ACR and other pathologies of the lung and airways. Blood samples could be routinely screened for levels of IL-6 protein. This will allow defining a normal cytokine profile in BAL and PB as well as cut-off values for ACR, as shown in the context of BAL cytology [90].

Advancing research on non-invasive biomarkers may eventually improve patient care. Using less-invasive assays will help to i) detect ACR at an earlier stage, ii) determine subclinical rejection, iii) develop drugs targeting specific molecular structures, iv) identify allograft recipients who benefit from reduction or modification of immunosuppressive drugs and v) recognize patients at risk for CLAD not identified by TBB [8].

So far cytokine profile analysis is not part of the routine diagnostic workup for suspected ACR. When used within the clinical context, cytokine and cytology profiles of BAL and serum samples might be useful to assist in decision-making and alter the likelihood for the presence or absence of ACR. Overall, BAL and serum samples are no substitutes for TBBs in the evaluation of lung function decline in lung transplant recipients, but may increase the diagnostic yield of bronchoscopy for detection of ACR.

\footnotetext{
Abbreviations

ACR: acute cellular rejection; AM: alveolar macrophages; BAL: bronchoalveolar lavage; BO: bronchiolitis obliterans; CLAD: chronic lung allograft dysfunction; CSF: colony-stimulating factor; ELISA: enzyme-linked immunosorbent assay; FCM: flow cytometry; GVHD: graft-versus-host disease; IFN: interferon; IFNY: interferon gamma; IL: interleukin; mRNA: messenger RNA; NK cells: natural killer cells; NPV: negative predictive value; NRAD: neutrophilic reversible allograft dysfunction; PB: peripheral blood; PCR: polymerase chain reaction; PPV: positive predictive value; RAS: restrictive allograft syndrome; RT-PCR: reverse transcription polymerase chain reaction; TBB: transbronchial biopsy: TGF: transforming growth factor; TGF- $\beta$ : transforming growth factor beta; Th1 cell: type 1 helper T cell; Th2 cell: type 2 helper T cell; TNF: tumor necrosis factor; TNF-a: tumor necrosis factor alpha
}

\section{Acknowledgements}

Not applicable.

\section{Funding}

No funding was received to write this review article.

\section{Availability of data and materials}

Data sharing not applicable (review article)

\section{Authors' contributions}

NES performed literature search and drafted and revised the manuscript. MMS reviewed all versions of the manuscript and assisted to write the final version. $C B$ reviewed all versions of the manuscript and assisted to write the final version. LCH and CAR outlined this article and assisted to write all drafts the final version. All authors read and approved the final manuscript.

\section{Ethics approval and consent to participate}

Not applicable.

\section{Consent for publication}

Not applicable.

\section{Competing interests}

The authors declare that they have no competing interests.

\section{Publisher's Note}

Springer Nature remains neutral with regard to jurisdictional claims in published maps and institutional affiliations.

\section{Author details}

'Division of Pulmonology, University Hospital Zurich, Rämistrasse 100, CH-8091 Zurich, Switzerland. ${ }^{2}$ Clinic for Internal Medicine, City Hospital Triemli, Birmensdorferstrasse 497, CH-8063 Zurich, Switzerland.

Received: 11 May 2017 Accepted: 2 August 2017

Published online: 07 August 2017

\section{References}

1. Yusen RD, Edwards LB, Dipchand Al, Goldfarb SB, Kucheryavaya AY, Levvey BJ, Lund LH, Meiser B, Rossano JW, Stehlik J. The registry of the International Society for Heart and Lung Transplantation: thirty-third adult lung and heart-lung transplant report-2016; focus theme: primary diagnostic indications for transplant. J Heart Lung Transplant. 2016;35:1170-84.

2. Greenland JR, Jones KD, Hays SR, Golden JA, Urisman A, Jewell NP, Caughey GH, Trivedi NN. Association of large-airway lymphocytic bronchitis with bronchiolitis obliterans syndrome. Am J Respir Crit Care Med. 2013;187:417-23.

3. Swanson SJ, Mentzer SJ, Reilly JJ, Bueno R, Lukanich JM, Jaklitsch MT, Kobzik L, Ingenito EP, Fuhlbrigge A, Donovan C, et al. Surveillance transbronchial lung biopsies: implication for survival after lung transplantation. J Thor Cardiovasc Surg. 2000;119:27-37.

4. Khalifah AP, Hachem RR, Chakinala MM, Yusen RD, Aloush A, Patterson GA, Mohanakumar T, Trulock EP, Walter MJ. Minimal acute rejection after lung transplantation: a risk for bronchiolitis obliterans syndrome. Am J Transplant 2005;5:2022-30.

5. Bhorade SM, Husain AN, Liao C, Li LC, Ahya VN, Baz MA, Valentine VG, Love RB, Seethamraju H, Alex CG, et al. Interobserver variability in grading transbronchial lung biopsy specimens after lung transplantation. Chest. 2013;143:1717-24.

6. Arcasoy SM, Berry G, Marboe CC, Tazelaar HD, Zamora MR, Wolters HJ, Fang KC, Keshavjee S. Pathologic interpretation of transbronchial biopsy for acute rejection of lung allograft is highly variable. Am J Transplant. 2011;11:320-8.

7. Diette GB, Wiener CM, White P Jr. The higher risk of bleeding in lung transplant recipients from bronchoscopy is independent of traditional bleeding risks: results of a prospective cohort study. Chest. 1999;115:397-402.

8. Greenland JR, Jewell NP, Gottschall M, Trivedi NN, Kukreja J, Hays SR, Singer JP, Golden JA, Caughey GH. Bronchoalveolar lavage cell immunophenotyping facilitates diagnosis of lung allograft rejection. Am J Transplant. 2014;14:831-40.

9. Stephenson A, Flint J, English J, Vedal S, Fradet G, Chittock D, Levy RD. Interpretation of transbronchial lung biopsies from lung transplant recipients: inter- and intraobserver agreement. Canadian Respiratory J. 2005;12:75-7. 
10. Hachem RR, Khalifah AP, Chakinala MM, Yusen RD, Aloush AA, Mohanakumar T, Patterson GA, Trulock EP, Walter MJ. The significance of a single episode of minimal acute rejection after lung transplantation. Transplantation. 2005;80:1406-13.

11. Speck NE, Schuurmans MM, Murer C, Benden C, Huber LC. Diagnostic value of plasma and bronchoalveolar lavage samples in acute lung allograft rejection: differential cytology. Respir Res. 2016;17:74.

12. Banks RE. Measurement of cytokines in clinical samples using immunoassays: problems and pitfalls. Crit Rev Clin Lab Sci. 2000;37:131-82.

13. Kelso A. Cytokines: principles and prospects. Immunol Cell Biol. 1998;76:300-17.

14. Tiroke AH, Bewig B, Haverich A. Bronchoalveolar lavage in lung transplantation. State of the art. Clin Transpl. 1999;13:131-57.

15. Wood KJ, Goto R. Mechanisms of rejection: current perspectives. Transplantation. 2012;93:1-10.

16. Whitehead BF, Stoehr C, Wu CJ, Patterson G, Burchard EG, Theodore J, Clayberger C, Starnes VA. Cytokine gene expression in human lung transplant recipients. Transplantation. 1993:56:956-61.

17. Wu CJ, Lovett M, Wong-Lee J, Moeller F, Kitamura M, Goralski TJ, Billingham ME, Starnes VA, Clayberger C. Cytokine gene expression in rejecting cardiac allografts. Transplantation. 1992;54:326-32.

18. Pavlakis M, Strehlau J, Lipman M, Shapiro M, Maslinski W, Strom TB. Intragraft IL-15 transcripts are increased in human renal allograft rejection. Transplantation. 1996;62:543-5.

19. Hoefakker S, Boersma WJ, Claassen E. Detection of human cytokines in situ using antibody and probe based methods. J Immunol Methods. 1995;185: 149-75

20. Dallman MJ, Montgomery RA, Larsen CP, Wanders A, Wells AF. Cytokine gene expression: analysis using northern blotting, polymerase chain reaction and in situ hybridization. Immunol Rev. 1991;119:163-79.

21. Hutchings PR, Cambridge G, Tite JP, Meager T, Cooke A. The detection and enumeration of cytokine-secreting cells in mice and man and the clinical application of these assays. J Immunol Methods. 1989;120:1-8.

22. Jung T, Schauer U, Heusser C, Neumann C, Rieger C. Detection of intracellular cytokines by flow cytometry. J Immunol Methods. 1993;159:197-207.

23. Mire-Sluis AR, Thorpe R. Laboratory protocols for the quantitation of cytokines by bioassay using cytokine responsive cell lines. J Immunol Methods. 1998;211:199-210.

24. Heidt S, San Segundo D, Shankar S, Mittal S, Muthusamy AS, Friend PJ, Fuggle SV, Wood KJ. Peripheral blood sampling for the detection of allograft rejection: biomarker identification and validation. Transplantation. 2011;92:1-9.

25. Anglicheau D, Suthanthiran M. Noninvasive prediction of organ graft rejection and outcome using gene expression patterns. Transplantation. 2008;86:192-9.

26. Suarez-Santamaria M, Santolaria F, Perez-Ramirez A, Aleman-Valls MR, Martinez-Riera A, Gonzalez-Reimers E, de la Vega MJ, Milena A. Prognostic value of inflammatory markers (notably cytokines and procalcitonin), nutritional assessment, and organ function in patients with sepsis. Eur Cytokine Netw. 2010;21:19-26.

27. Dinarello CA. Biologic basis for interleukin-1 in disease. Blood. 1996;87:2095-147.

28. Cullup H, Stark G. Interleukin-1 polymorphisms and graft-vs-host disease. Leuk Lymphoma. 2005;46:517-23.

29. Chang DM, Hsu K, Ding YA, Chiang CH. Interleukin-1 in ischemia-reperfusion acute lung injury. Am J Respir Crit Care Med. 1997;156:1230-4.

30. Borthwick LA, Corris PA, Mahida R, Walker A, Gardner A, Suwara M, Johnson GE, Moisey EJ, Brodlie M, Ward C, et al. TNFalpha from classically activated macrophages accentuates epithelial to mesenchymal transition in obliterative bronchiolitis. Am J Transplant. 2013;13:621-33.

31. Patella M, Anile M, Del Porto P, Diso D, Pecoraro Y, Onorati I, Mantovani S, De Giacomo T, Ascenzioni F, Rendina EA, Venuta F. Role of cytokine profile in the differential diagnosis between acute lung rejection and pulmonary infections after lung transplantation. Eur J Cardiothorac Surg. 2014;47(6):1031-36.

32. Rizzo M, SivaSai KS, Smith MA, Trulock EP, Lynch JP, Patterson GA Mohanakumar T. Increased expression of inflammatory cytokines and adhesion molecules by alveolar macrophages of human lung allograft recipients with acute rejection: decline with resolution of rejection. J Heart Lung Transplant. 2000;19:858-65.

33. Silva-Filho JL, Caruso-Neves C, Pinheiro AAS. IL-4: an important cytokine in determining the fate of T cells. Biophys Rev. 2014;6:111-8.

34. Hodge G, Hodge S, Chambers D, Reynolds PN, Holmes M. Acute lung transplant rejection is associated with localized increase in T-cell IFNgamma and TNFalpha proinflammatory cytokines in the airways. Transplantation. 2007:84:1452-8.

35. Hodge G, Hodge S, Reynolds PN, Holmes M. Increased intracellular pro- and anti-inflammatory cytokines in bronchoalveolar lavage T cells of stable lung transplant patients. Transplantation. 2005;80:1040-5.

36. Hunter CA, Jones SA. IL-6 as a keystone cytokine in health and disease. Nat Immunol. 2015;16:448-57.

37. Groth A, Vrugt B, Brock M, Speich R, Ulrich S, Huber LC. Inflammatory cytokines in pulmonary hypertension. Respir Res. 2014;15:47.

38. Rolfe MW, Kunkel S, Lincoln P, Deeb M, Lupinetti F, Strieter R. Lung allograft rejection: role of tumor necrosis factor-alpha and interleukin-6. Chest. 1993;103:133s.

39. Resende MR, Rajwans N, Pilewski JM, McCurry KR, Keshavjee S, Conrad Liles W, Husain S. Increased CXCL10 (IP-10) in bronchoalveolar lavage (BAL) is associated with acute rejection (ACR) in lung transplant recipients (LTR). J Heart Lung Transplant. 2011;30:S88.

40. lacono A, Dauber J, Keenan R, Spichty K, Cai J, Grgurich W, Burckart G, Smaldone G, Pham S, Ohori NP, et al. Interleukin 6 and interferon-gamma gene expression in lung transplant recipients with refractory acute cellular rejection: implications for monitoring and inhibition by treatment with aerosolized cyclosporine. Transplantation. 1997;64:263-9.

41. Husain S, Resende MR, Rajwans N, Zamel R, Pilewski JM, Crespo MM, Singer LG, McCurry KR, Kolls JK, Keshavjee S, Liles WC. Elevated CXCL10 (IP-10) in Bronchoalveolar Lavage fluid is associated with acute cellular rejection after human lung transplantation. Transplantation. 2014;97:90.

42. Slebos DJ, Postma DS, Koeter GH, Van Der Bij W, Boezen M, Kauffman HF. Bronchoalveolar lavage fluid characteristics in acute and chronic lung transplant rejection. J Heart Lung Transplant. 2004;23:532-40.

43. Magnan A, Mege JL, Reynaud M, Thomas P, Capo C, Garbe L, Meric B, Badier M, Bongrand P, Viard L. Monitoring of alveolar macrophage production of tumor necrosis factor-alpha and interleukin-6 in lung transplant recipients. Marseille and Montreal lung transplantation group. Am Jespir Crit Care Med. 1994;150:684-9.

44. Magnan A, Mege JL, Escallier JC, Brisse J, Capo C, Reynaud M, Thomas P, Meric B, Garbe L, Badier M, et al. Balance between alveolar macrophage IL-6 and TGF-beta in lung-transplant recipients. Marseille and Montreal lung transplantation group. Am J Respir Crit Care Med. 1996;153:1431-6.

45. Yoshida Y, Iwaki Y, Pham S, Dauber JH, Yousem SA, Zeevi A, Morita S, Griffith BP. Benefits of posttransplantation monitoring of interleukin 6 in lung transplantation. Ann Thorac Surg. 1993;55:89-93.

46. Humbert M, Delattre RM, Fattal S, Rain B, Cerrina J, Dartevelle P, Simonneau G, Duroux P, Galanaud P, Emilie D. In situ production of interleukin-6 within human lung allografts displaying rejection or cytomegalovirus pneumonia. Transplantation. 1993;56:623-7.

47. Baggiolini M, Walz A, Kunkel SL. Neutrophil-activating peptide-1/interleukin 8, a novel cytokine that activates neutrophils. J Clin Invest. 1989:84:1045-9.

48. Vos R, Verleden SE, Ruttens D, Vandermeulen E, Bellon H, Neyrinck A, Van Raemdonck DE, Yserbyt J, Dupont LJ, Verbeken EK, et al. Azithromycin and the treatment of lymphocytic airway inflammation after lung transplantation. Am J Transplant. 2014;14:2736-48.

49. Verleden SE, Vandermeulen E, Ruttens D, Vos R, Vaneylen A, Dupont L, Van Raemdonck DE, Vanaudenaerde BM, Verleden GM. Neutrophilic reversible allograft dysfunction (NRAD) and restrictive allograft syndrome (RAS). Semin Respir Crit Care Med. 2013:34:352-60.

50. Riise GC, Kjellstrom C, Ryd W, Schersten H, Nilsson F, Martensson G, Andersson BA. Inflammatory cells and activation markers in BAL during acute rejection and infection in lung transplant recipients: a prospective, longitudinal study. Eur Respir J. 1997;10:1742-6.

51. Vanaudenaerde BM, Dupont LJ, Wuyts WA, Verbeken EK, Meyts I, Bullens DM, Dilissen E, Luyts L, Van Raemdonck DE, Verleden GM. The role of interleukin-17 during acute rejection after lung transplantation. Eur Respir J. 2006;27:779-87.

52. Boehler A. The role of interleukin-10 in lung transplantation. Transpl Immunol. 2002;9:121-4.

53. Zou XM, Yagihashi A, Hirata K, Tsuruma T, Matsuno T, Tarumi K, Asanuma K, Watanabe N. Downregulation of cytokine-induced neutrophil chemoattractant and prolongation of rat liver allograft survival by interleukin-10. Surg Today. 1998;28:184-91.

54. DeBruyne LA, Li K, Chan SY, Qin L, Bishop DK, Bromberg JS. Lipid-mediated gene transfer of viral IL-10 prolongs vascularized cardiac allograft survival by inhibiting donor-specific cellular and humoral immune responses. Gene Ther. 1998:5:1079-87. 
55. Moudgil A, Bagga A, Toyoda M, Nicolaidou E, Jordan SC, Ross D. Expression of gamma-IFN mRNA in bronchoalveolar lavage fluid correlates with early acute allograft rejection in lung transplant recipients. Clin Transpl. 1999;13:201-7.

56. Ross DJ, Moudgil A, Bagga A, Toyoda M, Marchevsky AM, Kass RM, Jordan SC Lung allograft dysfunction correlates with gamma-interferon gene expression in bronchoalveolar lavage. J Heart Lung Transplant. 1999;18:627-36.

57. Zheng HX, Burckart GJ, McCurry K, Webber S, Ristich J, lacono A, Dauber J, McDade K, Grgurich W, Zaldonis D, et al. Interleukin-10 production genotype protects against acute persistent rejection after lung transplantation. J Heart Lung Transplant. 2004;23:541-6.

58. Oishi H, Okada Y, Kikuchi T, Hoshikawa Y, Sado T, Noda M, Endo C, Sakurada A, Matsumura Y, Kondo T. Transbronchial human interleukin-10 gene transfer reduces acute inflammation associated with allograft rejection and intragraft interleukin-2 and tumor necrosis factor-alpha gene expression in a rat model of lung transplantation. J Heart Lung Transplant. 2010;29:360-7.

59. Wood KJ, Bushell A, Hester J. Regulatory immune cells in transplantation. Nat Rev Immunol. 2012;12:417-30.

60. Fehniger TA, Caligiuri MA. Interleukin 15: biology and relevance to human disease. Blood. 2001;97:14-32.

61. Shi RL, Yang JB, Jaramillo A, Steward NS, Aloush A, Trulock EP, Patterson GA, Suthanthiran M, Mohanakumar T. Correlation between interleukin-15 and granzyme B expression and acute lung allograft rejection. Transpl Immunol. 2004;12:103-8

62. Bhorade SM, Yu A, Vigneswaran WT, Alex CG, Garrity ER. Elevation of interleukin-15 protein expression in bronchoalveolar fluid in acute lung allograft rejection. Chest. 2007;131:533-8.

63. Yao Z, Painter SL, Fanslow WC, Ulrich D, Macduff BM, Spriggs MK, Armitage RJ. Human IL-17: a novel cytokine derived from T cells. J Immunol. 1995;155:5483-6.

64. Vanaudenaerde BM, Wuyts WA, Dupont L, Van Raemdonck DE, Demedts MM, Verleden GM. Interleukin-17 stimulates release of interleukin-8 by human airway smooth muscle cells in vitro: a potential role for interleukin17 and airway smooth muscle cells in bronchiolitis obliterans syndrome. J Heart Lung Transplant. 2003;22:1280-3.

65. Linden A, Laan M, Anderson GP. Neutrophils, interleukin-17A and lung disease. Eur Respir J. 2005;25:159-72.

66. Snell GI, Levvey BJ, Zheng L, Bailey M, Orsida B, Williams TJ, Kotsimbos TC. Interleukin-17 and airway inflammation: a longitudinal airway biopsy study after lung transplantation. J Heart Lung Transplant. 2007;26:669-74.

67. Shilling RA, Wilkes DS. Role of Th17 cells and IL-17 in lung transplant rejection. Semin Immunopathol. 2011;33:129-34.

68. Schroder K, Hertzog PJ, Ravasi T, Hume DA. Interferon-gamma: an overview of signals, mechanisms and functions. J Leukoc Biol. 2004;75:163-89.

69. Chang SC, Hsu HK, Perng RP, Shiao GM, Lin CY. Significance of biochemical markers in early detection of canine lung allograft-rejection. Transplantation. 1991;51:579-84.

70. Sekine Y, Bowen LK, Heidler KM, Van Rooijen N, Brown JW, Cummings OW, Wilkes DS. Role of passenger leukocytes in allograft rejection: effect of depletion of donor alveolar macrophages on the local production of TNF-alpha, T helper 1/T helper 2 cytokines, IgG subclasses, and pathology in a rat model of lung transplantation. J Immunol. 1997;159:4084-93.

71. Gimino VJ, Lande JD, Berryman TR, King RA, Hertz MI. Gene expression profiling of bronchoalveolar lavage cells in acute lung rejection. Am J Respir Crit Care Med. 2003;168:1237-42.

72. Sundaresan S, Alevy YG, Steward N, Tucker J, Trulock EP, Cooper JD, Patterson GA, Mohanakumar T. Cytokine gene transcripts for tumornecrosis-factor-alpha, interleukin-2, interferon-gamma in human pulmonary allografts. J Heart Lung Transplantation. 1995;14:512-8.

73. Kalliolias GD, Ivashkiv LB. TNF biology, pathogenic mechanisms and emerging therapeutic strategies. Nat Rev Rheumatol. 2016;12:49-62.

74. DeMeester SR, Rolfe MW, Kunkel SL, Swiderski DL, Lincoln PM, Deeb GM, Strieter RM. The bimodal expression of tumor necrosis factor-alpha in association with rat lung reimplantation and allograft rejection. J Immunol. 1993:150:2494-505.

75. Schutte RJ, Parisi-Amon A, Reichert WM. Cytokine profiling using monocytes/macrophages cultured on common biomaterials with a range of surface chemistries. J Biomed Mater Res A. 2009;88:128-39.

76. Fattal-German M, Le Roy LF, Cerrina J, Lecerf F, Berrih-Aknin S. Expression and modulation of ICAM-1, TNF-alpha and RANTES in human alveolar macrophages from lung-transplant recipients in vitro. Transpl Immunol. 1998;6:183-92.
77. Ahn JY, Kim MH, Lim MJ, Park S, Lee SL, Yun YS, Song JY. The inhibitory effect of ginsan on TGF-beta mediated fibrotic process. J Cell Physiol. 2011;226:1241-7.

78. Sheng J, Chen W, Zhu HJ. The immune suppressive function of transforming growth factor-beta (TGF-beta) in human diseases. Growth Factors. 2015;33:92-101.

79. Yoshimura A, Wakabayashi Y, Mori T. Cellular and molecular basis for the regulation of inflammation by TGF-beta. J Biochem. 2010;147:781-92.

80. Agostini C, Calabrese F, Rea F, Facco M, Tosoni A, Loy M, Binotto G, Valente M, Trentin L, Semenzato G. Cxcr3 and its ligand CXCL10 are expressed by inflammatory cells infiltrating lung allografts and mediate chemotaxis of T cells at sites of rejection. Am J Pathol. 2001;158:1703-11.

81. Romagnani P, Crescioli C. CXCL10: a candidate biomarker in transplantation. Clin Chim Acta. 2012;413:1364-73.

82. Neujahr DC, Perez SD, Mohammed A, Ulukpo O, Lawrence EC, Fernandez F, Pickens A, Force SD, Song M, Larsen CP, Kirk AD. Cumulative exposure to gamma interferon-dependent chemokines CXCL9 and CXCL10 correlates with worse outcome after lung transplant. Am J Transplant. 2012;12:438-46.

83. Agostini C, Cassatella M, Zambello R, Trentin L, Gasperini S, Perin A, Piazza F, Siviero M, Facco M, Dziejman M, et al. Involvement of the IP-10 chemokine in sarcoid granulomatous reactions. J Immunol. 1998;161:6413-20.

84. Radhakrishna N, Farmer M, Steinfort DP, King P. A comparison of techniques for optimal performance of Bronchoalveolar Lavage. J Bronchology Interv Pulmonol. 2015;22:300-5.

85. Bollmann BA, Seeliger B, Drick N, Welte T, Gottlieb JT, Greer M. Cellular analysis in bronchoalveolar lavage: inherent limitations of current standard procedure. Eur Respir J. 2017;49(6):1601844. doi:10.1183/13993003.01844-2016.

86. Meyer KC, Raghu G, Baughman RP, Brown KK, Costabel U, du Bois RM, Drent M, Haslam PL, Kim DS, Nagai S, et al. An official American Thoracic Society clinical practice guideline: the clinical utility of bronchoalveolar lavage cellular analysis in interstitial lung disease. Am J Respir Crit Care Med. 2012;185:1004-14.

87. Roux-Lombard P, Steiner G. Preliminary report on cytokine determination in human synovial fluids: a consensus study of the European workshop for rheumatology research. The cytokine consensus study Group of the European Workshop for rheumatology research. Clin Exp Rheumatol. 1992; 10:515-20.

88. Bienvenu J, Coulon L, Doche C, Gutowski MC, Grau GE. Analytical performances of commercial ELISA-kits for IL-2, IL-6 and TNF-alpha. A WHO study Eur Cytokine Netw. 1993;4:447-51.

89. Ledur A, Fitting C, David B, Hamberger C, Cavaillon JM. Variable estimates of cytokine levels produced by commercial ELISA kits: results using international cytokine standards. J Immunol Methods. 1995;186:171-9.

90. Slebos DJ, Scholma J, Boezen HM, Koeter GH, van der Bij W, Postma DS, Kauffman HF. Longitudinal profile of bronchoalveolar lavage cell characteristics in patients with a good outcome after lung transplantation. Am J Respir Crit Care Med. 2002;165:501-7.

91. Akdis M, Burgler S, Crameri R, Eiwegger T, Fujita H, Gomez E, Klunker S, Meyer N, O'Mahony L, Palomares O, et al. Interleukins, from 1 to 37 , and interferon-gamma: receptors, functions, and roles in diseases. J Allergy Clin Immunol. 2011;127:701-21. e701-770

92. Platanias LC. Mechanisms of type--- and type-II-interferon-mediated signalling. Nat Rev Immunol. 2005;5:375-86.

93. Wakefield LM, Hill CS. Beyond TGFbeta: roles of other TGFbeta superfamily members in cancer. Nat Rev Cancer. 2013;13:328-41.

94. Hamilton JA. Colony-stimulating factors in inflammation and autoimmunity. Nat Rev Immunol. 2008:8:533-44.

95. Griffith JW, Sokol CL, Luster AD. Chemokines and chemokine receptors: positioning cells for host defense and immunity. Annu Rev Immunol. 2014; 32:659-702.

96. Fattal-German M, Le Roy LF, Lecerf F, Berrih-Aknin S. Expression of ICAM-1 and TNF alpha in human alveolar macrophages from lung-transplant recipients. Ann N Y Acad Sci. 1996;796:138-48.

97. Rondeau E, Cerrina J, Delarue F, Ladurie FL, Herve P, Chapelier A, Dartevelle P, Sraer JD. Tumor necrosis factor alpha (TNF-alpha) production by cells of bronchioloalveolar lavage (BAL) and peripheral blood mononuclear cells (PBMC) in cardiopulmonary transplant recipients. Transplant Proc. 1990;22:1855-6.

98. Dosanjh A, Robbins RC. Cytokines interleukin 5 and GM-CSF in the BAL fluid of lung transplant patients. Chest. 1998;114:349.

99. Rolfe MW, Kunkel SL, Demeester SR, Swiderski DL, Lincoln PM, Deeb GM, Strieter RM. Expression of interleukin-6 in association with rat lung reimplantation and allograft rejection. Am Rev Respir Dis. 1993;147:1010-6. 
100. Laan M, Linden A, Riise GC. IL-16 in the airways of lung allograft recipients with acute rejection or obliterative bronchiolitis. Clin Exp Immunol. 2003; 133:290-6.

101. Ericson P, Linden A, Riise GC. BAL levels of interleukin-18 do not change before or during acute rejection in lungtransplant recipients. Respir Med. 2004:98:159-63.

Submit your next manuscript to BioMed Central and we will help you at every step:

- We accept pre-submission inquiries

- Our selector tool helps you to find the most relevant journal

- We provide round the clock customer support

- Convenient online submission

- Thorough peer review

- Inclusion in PubMed and all major indexing services

- Maximum visibility for your research

Submit your manuscript at www.biomedcentral.com/submit 